\title{
Metagenomic analysis and biodiversity of Lactic Acid Bacteria (LAB) on masin (fermented sauce) from Sumbawa, West Nusa Tenggara, Indonesia
}

\author{
BASO MANGUNTUNGI ${ }^{1, \bullet}$, DINAR SUKSMAYU SAPUTRI ${ }^{2}$, APON ZAENAL MUSTOPA ${ }^{3, \bullet}$, \\ NURLAILI EKAWATI ${ }^{3}$, CHAIRUL ANAM AFGANI ${ }^{4}$, ARLINDA PUSPITA SARI ${ }^{5}$, LITA TRIRATNA ${ }^{3}$, \\ LINDA SUKMARINI ${ }^{3}$, FATIMAH ${ }^{6}$, AMIRIN KUSMIRAN ${ }^{7}$, SAHRI YANTI ${ }^{2}$, SHASMITA IRAWAN ${ }^{3}$, \\ MUHAMMAD DWI PRASETYO ${ }^{8}$, KHADIJAH ALLIYA FIDIEN ${ }^{1}$ \\ ${ }^{1}$ Department of Biotechnology, Faculty of Biotechnology, Universitas Teknologi Sumbawa. Jl. Olat Maras, Moyo Hulu, Sumbawa 84371, West Nusa \\ Tenggara, Indonesia. Tel./fax: +62-371-2629009, •email: baso.manguntungi@uts.ac.id \\ ${ }^{2}$ Department and Graduate Institute of Applied Chemistry, Chaoyang University of Technology,168, Jifeng E. Rd., Wufeng District, Taichung, 41349 , \\ Taiwan \\ ${ }^{3}$ Research Center for Biotechnology, Indonesia Institute of Science. Jl. Raya Bogor Km. 46, Cibinong, Bogor 16911, West Java, Indonesia. \\ Tel.: +62-21-8754587, Fax.: +62-21-8754588, v•email: azmustopa@ yahoo.com \\ ${ }^{4}$ Department of Agricutural Product Technology, Faculty of Agricultural Technology, Universitas Teknologi Sumbawa. Jl. Raya Olat Maras, Moyo Hulu, \\ Sumbawa 84371, West Nusa Tenggara, Indonesia \\ ${ }^{5}$ Departement of Biology Education, Universitas Sulawesi Barat. J1. Prof. Dr. Baharuddin Lopa, Majene 91412, West Sulawesi, Indonesia \\ ${ }^{6}$ Indonesian Center for Agricultural Biotechnology and Genetic Resources Research and Development. Jl. TentaraPelajar No. 3A, Cimanggu, Bogor \\ 16111, West Java, Indonesia \\ ${ }^{7}$ Department of Science and Technology, Universitas Islam Negeri Alauddin Makassar. Jl. Sultan Alauddin No. 63, Gowa 92113, South Sulawesi, \\ Indonesia \\ ${ }^{8}$ Department of Biotechnology, Institut Pertatian Bogor. Jl. Raya Dramaga, Bogor 16680, West Java, Indonesia
}

Manuscript received: 7 April 2020. Revision accepted: 25 June 2020.

\begin{abstract}
Manguntungi B, Saputri DS, Mustopa AZ, Ekawati N, Afgani CA, Sari AP, Triratna L, Sukmarini L, Fatimah, Kusmiran A, Yanti S, Irawan S, Prasetyo MD, Fidien KA. 2020. Metagenomic analysis and biodiversity of Lactic Acid Bacteria (LAB) on masin (fermented sauce) from Sumbawa, West Nusa Tenggara, Indonesia. Biodiversitas 21: 3287-3293. Masin is a spontaneously fermented sauce from Sumbawa, West Nusa Tenggara Indonesia that is made of shrimp paste, chili, turmeric flower, and herbs mixed with some spices. This study aims to isolate Lactic Acid Bacteria (LAB) and analyze the metagenomic and biodiversity of its bacteria. Genome isolation for metagenomic analysis was using ZymoBIOMICS ${ }^{\mathrm{TM}}$ DNA Miniprep Kit. Sequencing analysis to identify LAB strain form masin was using $16 \mathrm{~S}$ rRNA universal primer. Metagenomic analysis showed that relative abundance bacteria in masin for order taxon was Lactobacillales, the family taxon was Enteroccocaceae, and the genus was Tetragenoccocus. Six different groups were obtained from the phylogenetic tree analysis of 40 isolates found in masin. The representatives of each group taken were isolates number 2, 17, $11,34,28$, and 5. Based on the results of sequencing analysis, the 6 isolates found in masin are Staphylococcus piscifermentans strain CIP103958 (Isolate Code 2), S. piscifermentans strain BULST54 (Isolate Code 17), S. piscifermentans strain SK03 (Isolate Code 11), S. piscifermentans strain ATCC 51136 (Isolate Code 34), S. piscifermentans strain PCM 2409 (Isolate Code 28) and S. piscifermentans strain PU-87 (Isolate Code 5). Through this research, it has been described a whole diversity of bacteria contained in masin, one of them is Lactic acid bacteria. The six LAB isolates that have been identified can be developed as starter candidates for masin production.
\end{abstract}

Keywords: Biodiversity, LAB, masin, metagenomics

\section{INTRODUCTION}

Masin is a fermented product by using shrimp as the main ingredient and is widely consumed in Sumbawa. Bacteria that ferment masin were unidentified. The process was spontaneous without a starter. Masin producers prefer to rely on the quality of their production on natural microorganisms. In some fermented products, commercial starters often against the possibility in obtaining a unique product, change the sensory quality, and no longer distinguishable for production technology and geographical origin (Speranza et al. 2017). Spontaneous fermentation could develop potential pathogens (Manguntungi et al
2020) and toxic compounds that lead to the production of undesired metabolites (Lavefve et al. 2019).

One type of beneficial bacteria that is often found in food fermentation products is LAB. Bacteria isolated from peda (Indonesian fermented fish product) consist of Lactobacillus plantarum, Lactobacillus curvatus, Lactobacillus murinus, Streptococcus thermophilus (Putra et al. 2018). L. plantarum and Lactobacillus pentosus isolated from pekasam, Malaysian fermented fish (Muryany et al. 2017). Staphylococcus, Micrococcus and Bacillus were found in punti shidal and phasa shidal, fermented fish products in India (Majumdar et al. 2016). Staphylococcus piscifermentans was found in Cincaluk, fermented shrimp from Riau Indonesia, while $L$. 
plantarum, Staphylococcus xylosus, Saccharomyces cerevisiae were found in low salt traditional Chinese fermented fish, suanyu (Azam et al. 2017). However, the research on lactic acid bacteria in masin is still limited.

LAB can improve the quality of the products. The main bioactive compounds produced by LAB during fermentation are vitamins, $\gamma$-aminobutyric acid, bioactive peptides, bacteriocins, enzymes, conjugated linoleic acid, and exopolysaccharide. These compounds are the main biopreservative and have functional properties such as antioxidant and anti-diabetic (Speranza et al. 2017; Muryany et al. 2017; Linares et al. 2017; Mokoena et al. 2016).

LAB also has the ability to inhibit pathogen growth by disrupting the outer membrane of bacteria that causes lysis. LAB produces bacteriocins such as nisin, lactococcin, and lactacin by Lactobacillus lactis, pediocin by L. plantarum, and garvieacin by Lactobacillus garvieae. These antimicrobial peptides at a low concentration as picomolar to nanomolar exhibit the ability to permeabilize the cytoplasmic membrane of the receptor bacteria, resulting in a leakage of ions and small molecules into the cell. Bacteriocin-producing cultures have been applied to inhibit a wide range of Gram-positive genera, including staphylococci, streptococci, Listeria spp., bacilli, and enterococci in various fermented foods. LAB bacteriocins are GRAS (Generally Recognized as Safe) in food because it can be digested by proteases and have no or little influence on the gut microbiota (Mokoena et al. 2016; Woraprayote et al. 2016; Silva et al. 2016).

This study aimed to analyze the metagenome and biodiversity of LAB on masin. Through this metagenomic analysis, both potential and pathogenic bacterial diversity would be found in masin. Therefore, masin producers would be able to develop better products.

\section{MATERIALS AND METHODS}

\section{Study area}

Sumbawa is one of the districts in West Nusa Tenggara (NTB). Sumbawa is famous for one of its local fermented products, which is masin. The study began from June to August 2019. The research was conducted at the Laboratory of Applied Genetic Engineering and Protein Design, Biotechnology Research Center, Indonesian Institute of Sciences, Bogor, West Java, Indonesia.

\section{Procedures}

Sample preparation

Masin samples were obtained from Empang Subdistrict, Sumbawa District, West Nusa Tenggara, Indonesia. Masin is stored at $4^{\circ} \mathrm{C}$ to avoid spoilage.

\section{Genome isolation for metagenomic analysis}

Genome isolation was using ZymoBIOMICS ${ }^{\mathrm{TM}}$ DNA Miniprep Kit (Zymo Research, USA) $250 \mathrm{mg}$ of masin was

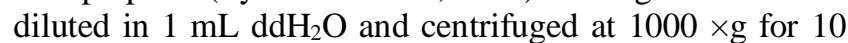
minutes. Supernatant was transferred into Lysis tube and centrifuged at $6000 \mathrm{rpm}$ for 10 minutes. $750 \mu \mathrm{L}$ Lysis solution was added to pellet and mixed for 20 minutes. Solution then was centrifuged at $10000 \times \mathrm{g}$ for 1 minute. $400 \mu \mathrm{L}$ supernatant was filtered and centrifuged at $8000 \times \mathrm{g}$ for 1 minute. $1200 \mu \mathrm{L}$ DNA binding buffer was mixed with the filtrate. The mixture was transferred to IICR column and centrifuged at $10000 \times \mathrm{g}$ for 1 minute. DNA wash buffer was added 3 times $(400,700$, and $200 \mu \mathrm{L})$ followed by 1 -minute centrifugation at $10000 \times \mathrm{g}$ for each addition. The IICR column transferred to a clean microtube, $45 \mu \mathrm{L}$ of DNase/RNase Free Water was added, incubated for 1 minute and centrifuged at $10,000 \times \mathrm{g}$ for 1 minute to elute the DNA. The result was visualized with gel electrophoresis on $1 \%(\mathrm{w} / \mathrm{v})$ agarose gel by using 1xTAE buffer. The gel was stained in a solution of Ethidium bromide and viewed using UV transilluminator.

\section{Sequencing analysis of metagenomic}

The next-generation sequencing analysis was performed at Novogene CO., Ltd Japan using Illumina (MiSeq) platform (paired-end reads). Paired-end reads were merged using FLASH (Magoč and Salzberg 2011). Primers used in this sequencing were V3-V4 region for bacteria (341F: 5'CCT AYG GGR BGC ASC AG-3'; 806R: 5'-GGA CTA CNN GGG TAT CTA AT-3'). Quality filtering on the raw tags was performed under specific filtering conditions to obtain the high-quality clean tags (Bokulich et al. 2013) according to the Qiime (V1.7.0) (Caporaso et al. 2010) quality controlled process. In order to detect chimera sequences using UCHIME algorithm (Edgar et al. 2011). Sequence analysis was performed by Uparse software (Edgar RC 2013) and the similarity of OTU was aligned with references from SILVA database (Quast et al. 2013).

\section{$L A B$ isolation}

Isolation was carried out by suspending $100 \mathrm{mg}$ of masin in $5 \mathrm{~mL}$ of MRS Broth with various concentrations of lactose and glucose. There are ten various compositions and concentrations (MRS control, MRS + glucose 1\%, MRS + glucose 2\%, MRS + lactose 1\%, MRS + lactose $2 \%, \mathrm{M} 17$ control, M17 + glucose $1 \%, \mathrm{M} 17+$ glucose $2 \%$, $\mathrm{M} 17+$ lactose $1 \%$, and M17 + lactose 2\%). The isolates then incubated overnight at $37^{\circ} \mathrm{C}$. After incubation, $100 \mu \mathrm{L}$ cultures were serially diluted in $900 \mu \mathrm{L}$ of $\mathrm{NaCl} 0.85 \%$. Serial dilution was conducted until dilution $10^{-7}$. A total of $100 \mu \mathrm{L}$ from $10^{-5}, 10^{-6}$ and $10^{-7}$ dilutions were taken and spread on MRS Agar with the treatment of adding lactose and glucose. The culture was incubated for 24 hours at $37^{\circ} \mathrm{C}$. A single colony that grows then subcultured on MRS Broth for DNA isolation.

\section{DNA isolation}

$1.5 \mathrm{~mL}$ of liquid culture was taken in microtube and centrifuged at $6000 \times \mathrm{g}$ for 10 minutes at $4^{\circ} \mathrm{C}$. $1.5 \mathrm{~mL}$ of liquid culture was added to pellet and re-centrifuged at $6000 \times \mathrm{g}$ for 10 minutes at $4^{\circ} \mathrm{C}$. Supernatant was discarded and pellet was added with $500 \mu \mathrm{L}$ TE buffer $\mathrm{pH} 8$ and 40 $\mu \mathrm{L}$ Lysozyme $(60 \mathrm{mg} / \mathrm{mL})$, then incubated $37^{\circ} \mathrm{C}$ for 60 minutes. After incubation, $200 \mu \mathrm{L} 10 \%$ SDS, $100 \mu \mathrm{L} 5 \mathrm{M}$ $\mathrm{NaCl}, 80 \mu \mathrm{L} 10 \% \mathrm{CTAB}$ were added to microtube and then incubated at $60^{\circ} \mathrm{C}$ for 30 minutes (invert microtube every 
10 minutes). $700 \mu \mathrm{L}$ of chloroform 1: 1 was added and centrifuged at $13000 \times \mathrm{g}$ for 10 minutes at $4^{\circ} \mathrm{C}$. The supernatant was transferred to new microtube and added $0.6 \times \mathrm{v}$ isopropanol, then incubated for 2 hours at $-20^{\circ} \mathrm{C}$. After incubation, microtube was centrifuged at $13000 \times \mathrm{g}$ for 10 minutes, $4^{\circ} \mathrm{C}$. The supernatant was discharged. Pellets were added with $1 \mathrm{~mL}$ of ethanol $70 \%$ and centrifuged at $13000 \times \mathrm{g}$ for 10 minutes, $4^{\circ} \mathrm{C}$. The supernatant was discarded and the pellet is dried overnight. The pellets were added $30 \mu \mathrm{L} \mathrm{ddH}_{2} \mathrm{O}$ and $5 \mu \mathrm{L}$ RNAse (1 $\mathrm{mg} / \mathrm{mL}$ ) and then incubated $37^{\circ} \mathrm{C}$ for 60 minutes. After that, the results of DNA isolation were stored at a low temperature to avoid DNA degradation (Lahiri and Schnabel 1993) and analyzed with gel electrophoresis on $2 \%(\mathrm{w} / \mathrm{v})$ agarose gel by using $1 \times$ TAE buffer. Then the gel was stained in ethidium bromide solution and using UV transilluminator to analyze it.

\section{RAPD bacteria isolates from masin}

Random Amplified Polymorphism DNA is a PCRbased discrimination method in which short arbitrary primers anneal to multiple random target sequences, resulting in patterns of diagnostic value (Mohania et al. 2008). RAPD used to identify the level of genetic diversity in LAB. Each reaction mixture (final volume $15 \mu \mathrm{L}$ ) was contained $3 \mu \mathrm{L}$ ddH2O, $7.5 \mu \mathrm{L} 5 \times$ My Taq (Bioline), 1.5 $\mu \mathrm{L}$ primers and $3 \mu \mathrm{L}$ DNA Templates (LAB Genome). The primers used are GTG5. The PCR method performed using the GTG5 primer (5'-GTGGTGGTGGTGGTG-3 ') was previously (Gevers et al. 2001). The cycling program consisted of 1 cycle of $95^{\circ} \mathrm{C}$ for 7 minutes; 30 cycles of $95^{\circ} \mathrm{C}$ for 1 minute, $55^{\circ} \mathrm{C}$ for 1 minute, and $65^{\circ} \mathrm{C}$ for 8 minutes; and finally 1 cycle of $65^{\circ} \mathrm{C}$ for 16 minutes. PCR products were analyzed by gel electrophoresis on $2 \%(\mathrm{w} / \mathrm{v})$ agarose gel using $1 \times$ TAE buffer. The gel was stained in a solution of Ethidium bromide and viewed using UV transilluminator.

\section{S rRNA PCR analysis and sequencing analysis}

PCR16S rRNA is a step to identify LAB strains found in masin using a $16 \mathrm{~S}$ rRNA universal primer. The primers sequences used are $8 \mathrm{~F}$ (5'AGAGTTTGATCATGGCTCAG-3') and 15R (5'AAGGAGGTGATCCAACCGCA-3'). Positions 1541 to $1522 \mathrm{bp}$ are used to amplify the overall fragment length of $16 \mathrm{~S}$ rRNA bacteria (Kazuko et al. 1992). The reaction mixture of PCR includes $\mathrm{ddH}_{2} \mathrm{O} 38.5 \mu \mathrm{L}, 5 \times$ MyTaq Green $7.5 \mu \mathrm{L}, 1 \mu \mathrm{L}$ of each primer, DNA templates (LAB genome) $2 \mu \mathrm{L}$ so that the total is $50 \mu \mathrm{L}$. The PCR conditions were $96^{\circ} \mathrm{C}$ for 5 minutes; 35 cycles consisting of $96^{\circ} \mathrm{C}$ for 1 minute, $55^{\circ} \mathrm{C}$ for 30 seconds, and $72^{\circ} \mathrm{C}$ for 1 minute; and $72^{\circ} \mathrm{C}$ for 7 minutes. The PCR products were subjected to electrophoresis gel on $1 \%$ agarose gel, followed by ethidium bromide staining. Sequencing results were analyzed using the Basic Local Alignment Search Tool (BLAST) in the NCBI and MegaX Software.

\section{RESULTS AND DISCUSSION}

\section{Results}

Molecular analysis is one of the methods to identify bacteria in masin. These bacteria are potential for further development into commercial starters. Through this research, metagenomic mapping of bacteria contained on masin was compiled. Figure 1 and Figure 2 are results of analysis metagenomic data from bacteria contained on masin. The results obtained all the bacteria found in the masin. Most of the bacteria belong to the bacilli class. In the taxon order, bacteria are dominated by the order Lactobacillales, whereas in the taxon family is dominated by Enteroccocaceae.

Based on that metagenomic analysis, some of the bacteria may be lactic acid bacteria. The selection of LAB was done by growing the bacteria in various modifications of growth media special for LAB as shown in Table 1. LAB has different media compositions according to their respective types. Some LABs display colony forms and the production of secondary metabolites which vary according to the type of medium (Hajar and Hamid 2013). Based on the results obtained in Table 1., after incubated for 2-4 days most LAB colonies were found on MRS + Lactose $2 \%$ media.

DNA was isolated to identify the types of LAB contained on masin. Bacterial DNA isolation was done by taking 4 isolates in each type of media, so there were 40 isolates obtained. Figure 3 shows the result of RAPD analysis conducted on 40 isolates.

Figure 4 shows the phylogeny of $40 \mathrm{LAB}$ isolates. It appears that there are 6 large groups of LAB types with the highest genetic relation. DNA structure of one isolate for each group was analyzed to determine the LAB type.

From the phylogeny tree of $40 \mathrm{LAB}$ isolates found on masin, there were 6 different groups. These groups were obtained based on the similarity of each isolate. The representatives of each group taken were isolates numbers $2,17,11,34,28$, and 5 each of which was then sequenced to determine the specific isolate types. The results of the sequence analysis of the 6 isolates are figured out in Table 2.

Based on the results of sequencing analysis, the 6 isolates found in masin are $S$. piscifermentans strain CIP103958 (Isolate Code 2), S. piscifermentans strain BULST54 (Isolate Code 17), S. piscifermentans strain SK03 (Isolate Code 11), S. piscifermentans strain ATCC 51136 (Isolate Code 34), S. piscifermentans strain PCM 2409 (Isolate Code 28) and S. piscifermentans strain PU-87 (Isolate Code 5). The results of DNA analysis carried out on LAB isolated from masin showed the same species in all isolate groups, which is $S$. piscifermentans. However, these species have different strains. The amount of these species ranges from $0.099 \%-0.10 \%$ of all bacteria found in the masin (Figure 2). These results indicate that all of bacteria mapped through previous metagenomic analysis, some of them are Lactic acid bacteria of the type $S$. piscifermentans. 


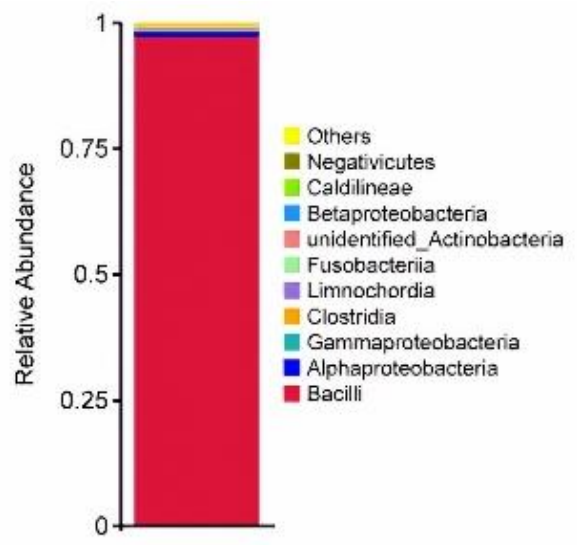

(a)

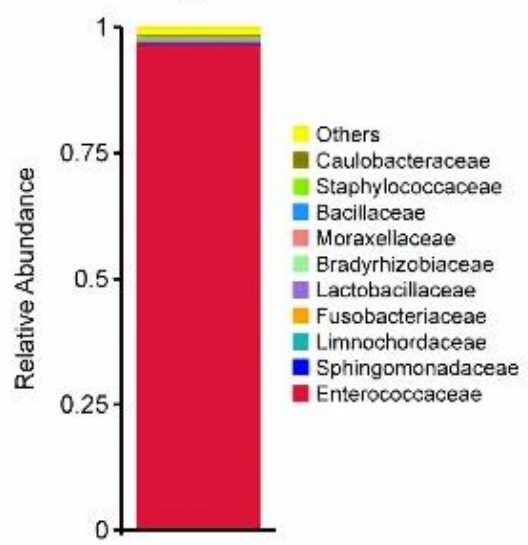

(c)

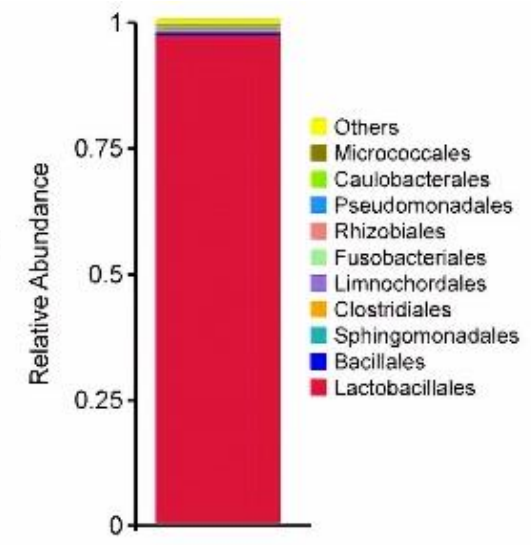

(b)

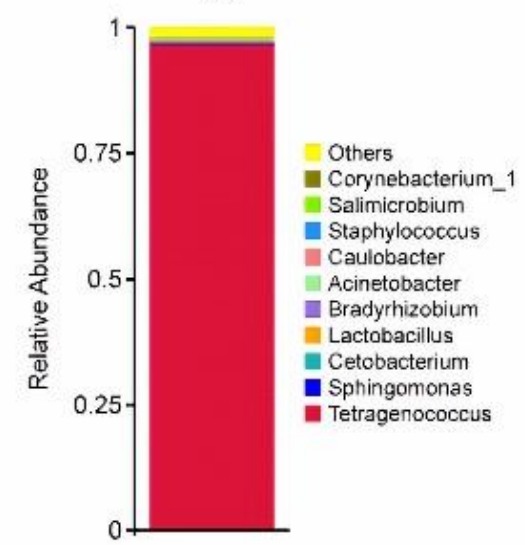

(d)

Figure 1. Relative abundance of bacteria in masin. The average bacterial abundance at each taxon level found in masin products is based on metagenomic analysis. A. Relative abundance of classes in bacteria isolated from masin; B. Metagenomic of the order in bacteria isolated from masin; C. Metagenomic of family in bacteria isolated from masin; D. Metagenomic of genus in bacteria isolated from masin.

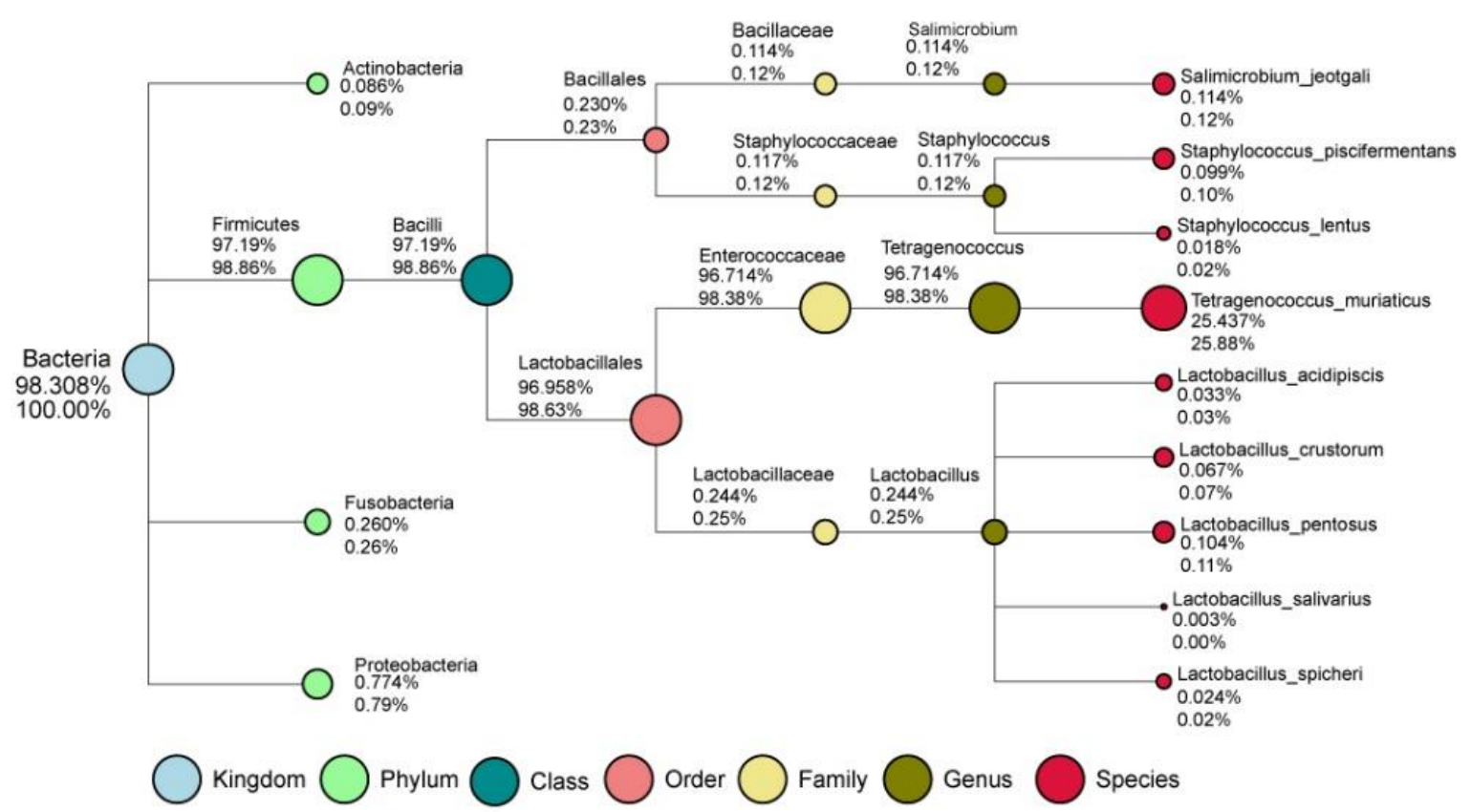

Figure 2. Phylogenetic of bacteria in masin. Phylogenetic of bacteria found in masin based on metagenomic analysis. The larger circle/sign indicates the greater number of bacteria at each taxon level which is also indicated by a percentage 

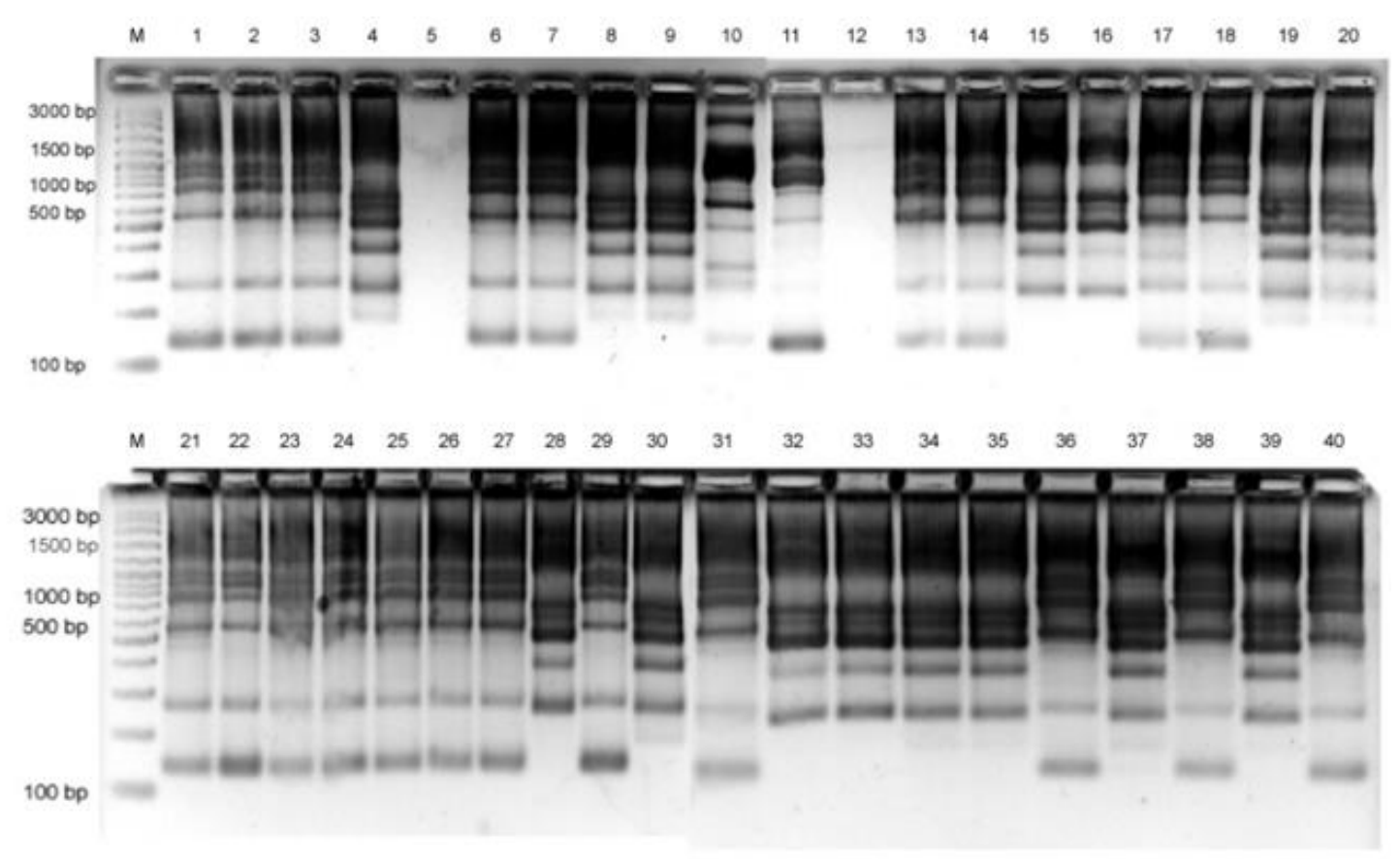

Figure 3. Visualization of PCR-RAPD band pattern of bacteria isolate code 1-40

\section{Discussion}

Bacilli class are the most dominant bacteria in masin $(97.19 \%-98.86 \%)$. At the level of taxonomic order, Lactobacillales is the most dominant (96,958\%-98.63\%). This order is most represented by Lactic acid bacteria and has the ability to produce lactic acid through carbohydrate fermentation (Subagiyo et al. 2015; Mekadim et al. 2018). Then at the Genera level, Tetragenoccocus became the most dominant (98.38\%). Meanwhile, at the species level, Tetragenoccocus muricatus is the most dominant species $(25 \%)$. In a study that isolated Lactic acid bacteria from the penaeid shrimp intestine, it was found that one of the bacteria was $T$. muricatus which grew well under medium conditions with the addition of $7 \% \mathrm{NaCl}$, but produced the highest lactic acid at $15 \% \mathrm{NaCl}$ addition (Reuter 1985). During the production of a fermented product, microorganisms transform raw material into a product that has better quality, generally by extending the shelf life of the raw materials and increasing the nutritional value of the product by improving the production of organoleptic attributes. Metagenomic approach has enabled exploration of microbial compositions in a range of traditional fermented foods while bypassing the need for cultivation, allowing the identification of a vast array of microorganisms never previously isolated in culture (Zhang et al. 2016).

Table 1. Population of LAB in several media

\begin{tabular}{lcc}
\hline Media treatment & Isolate code & CFU/g (10 \\
\hline MRS Control & $1-4$ & 15.85 \\
MRS + Glucose 1\% & $5-8$ & 18.90 \\
MRS + Glucose 2\% & $9-12$ & 16.57 \\
MRS + Lactose 1\% & $13-16$ & 17.00 \\
MRS + Lactose 2\% & $17-20$ & 20.65 \\
M17 Control & $21-24$ & 4.50 \\
M17 + Glucose 1\% & $25-28$ & 9.85 \\
M17 + Glucose 2\% & $29-32$ & 13.65 \\
M17 + Lactose 1\% & $33-36$ & 8.50 \\
M17 + Lactose 2\% & $37-40$ & 12.65 \\
\hline
\end{tabular}

Table 2. The result of sequencing analysis of $6 \mathrm{LAB}$ isolates

\begin{tabular}{llll}
\hline Isolates code & Species & \% identity & Accession number \\
\hline 2 & Staphylococcus piscifermentans strain CIP103958 & $99.93 \%$ & NR_116436.1 \\
17 & Staphylococcus piscifermentans strain BULST54 & $97.71 \%$ & MK7747756.1 \\
11 & Staphylococcus piscifermentans strain SK03 & $99.53 \%$ & NR_036981.1 \\
34 & Staphylococcus piscifermentans strain ATCC 51136 & $99.65 \%$ & NR_112035.1 \\
28 & Staphylococcus piscifermentans strain PCM 2409 & $100 \%$ & MF678955.1 \\
5 & Staphylococcus piscifermentans strain PU-87 & $99.86 \%$ & Y15753.1 \\
\hline
\end{tabular}




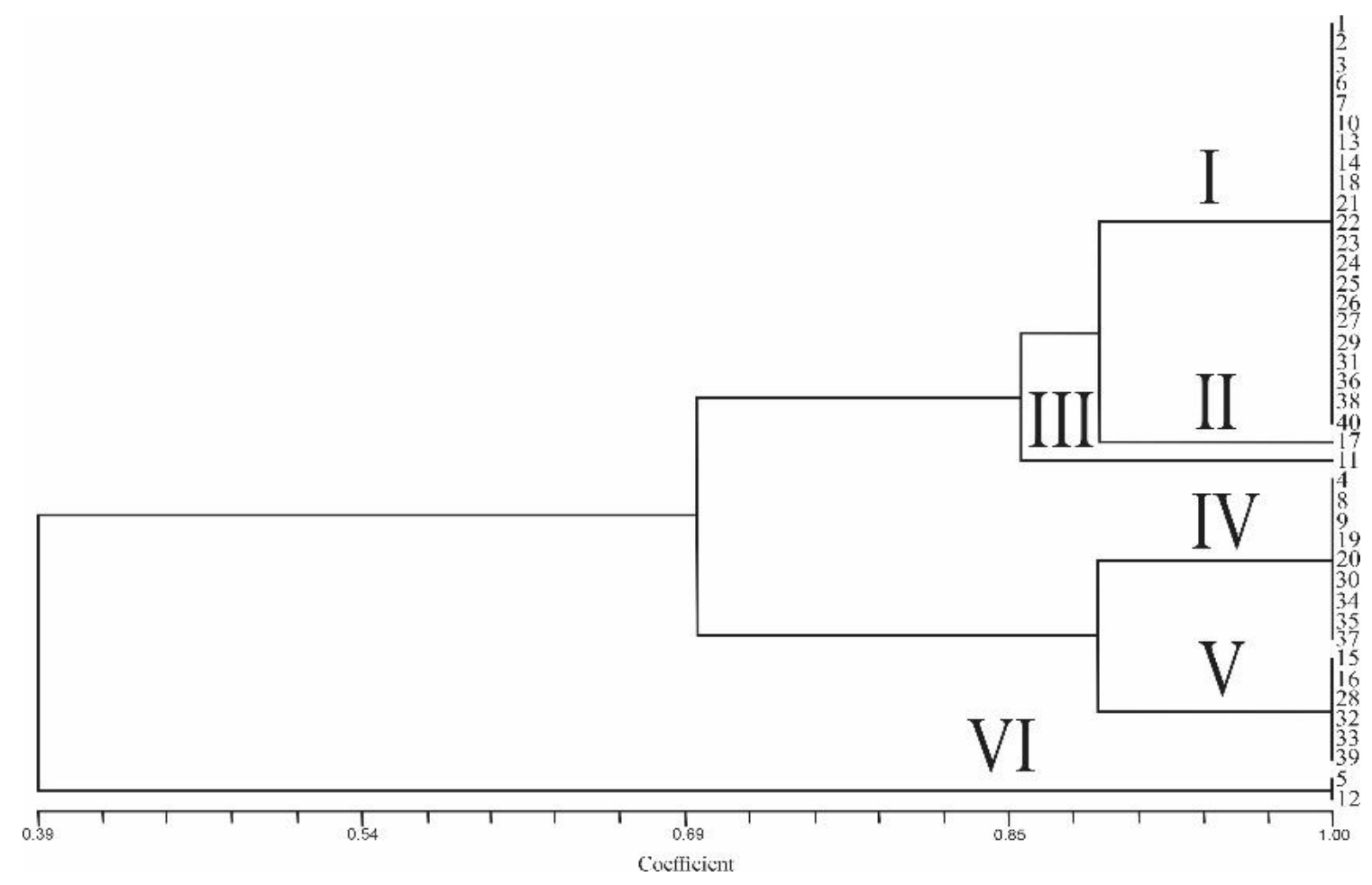

Figure 4. Phylogenetic tree of LAB found on masin

However, several LAB also isolated from fermented fish products. Yucha, traditional fermented food made from cooked rice and fresh fish. At the genus level, yucha contains an abundant amount of Lactobacillus (Firmicutes phylum) (Zhang et al. 2016). Alkaliphilic LAB belonging to the genera Marini lactobacillus and Jeotgalibaca have been detected in fermented skate, also known as hongeo, a traditional fermented fish product in South Korea. The difference of bacterial structure in different hongeo samples might be associated with the different fermentation environments in different fish processing plants, such as temperature, humidity, and other processing steps (Zhao and Eun 2020). LAB Tetragenococus halophilus were found in fermented fish sauce from Vietnam (Nga et al. 2017). Gammaproteobacteria, Bacilli, Psychrobacter and Lactobacillus isolated from Norwegian fermented fish (rakfisk), made of mild salting salmonid freshwater fish (Bjerke et al. 2019).

The results of DNA analysis carried out on LAB isolated from masin showed the presence of similar species in all isolate groups, which is S. piscifermentans. This species is also found in typical Malaysian shrimp fermentation products (cincaluk) and in fermented fish products and soy sauce from Thailand (Tanasupawat et al 1992).

Staphylococcus piscifermentans strain is Generally Recognized as Safe (GRAS) organism that commonly found in fermented foods including fermented fish, soy sauce, sausages, and traditional salted meat. $S$. piscifermentans is a non-pathogenic Gram-positive that is used as part of starter cultures for fish fermentation combined with $S$. canosus and $S$. condimentii. In fermented fish product in India, S. piscifermentans has shown the capability to prevent the growth of undesirable bacteria, decrease $\mathrm{pH}$, hydrogen peroxide, develop flavor and red color (Gupta et al. 2018; Ouobaa et al. 2019).

Food such as dairies and vegetables is the right ecosystem for LAB. Hence, it is common to find bioactive molecules in fermented products. LAB proteolytic system has the capability to produce molecules from proteins present in food matrices. These bioactive compounds are effective for anti-hypertensive, anti-thrombotic, cholesterol-lowering, metal-chelating, antimicrobial, antioxidant, immune-modulating and to treat reproductive behavior (Pessione and Cirrincione 2016).

LAB strains produce substances such as reuterin, reutericyclin, diacetyl, fatty acids, and hydrogen peroxide, propionate, phenyl-lactate, hydroxyphenyl-lactate and 3hydroxy fatty acids that play a role as antimicrobial and antifungal for foods biopreservation (Castellano et al. 2017). Lacticin from Lactococci, macedovicin from Streptococcus macedonicus, reuterin from Lactobacillus reuteri, sakacin from Lactobacillus sake, curvacin A, curvaticin and lactocin from Lactobacillus curvatus, pediocin from Pediococcus acidilactici, plantaricins from Lactobacillus plantarum are bacteriocins that have proved to control of spoilage and pathogenic bacteria in food (Bintsis 2018).

With the identification of bacteria types in masin products through metagenomics, the development of fermented products is expected to be better. Specifically through the use of LAB as a starter for the production of masin is expected to improve the quality of the product itself. 


\section{ACKNOWLEDGEMENTS}

This research was funded by Ministry of Research, Technology and Higher Education (Indonesia) with Program Pengembangan Teknologi Industri (PPTI) 2019. All facilities were supported by Research Center for Biotechnology, Indonesian Institute of Sciences (LIPI), Bogor, West Java and Indonesian Center for Agricultural Biotechnology and Genetic Resources Research and Development (ICABIOGRAD), Bogor, West Java. The authors would like to thank Leggyna Rezzy Vanggy and Hanifah Hanjani Putri (Department of Biotechnology, Faculty of Biotechnology, Sumbawa University of Technology, Indonesia)

\section{REFERENCES}

Azam M, Mohsin M, Ijaz H, Tulain UR, Ashraf MA, Fayyaz A, Abadeen Z, Kamran Q. 2017. Review: Lactic acid bacteria in traditional fermented Asian foods. Pak J Pharm Sci 30 (5): 1803-1814.

Bintsis T. 2018. Review: Lactic acid bacteria: their applications in foods. J Bacteriol Mycol 6 (2): 89-94

Bjerke GA, Rudi K, Avershina E, Moen B, Blom H, Axelsson L. 2019. Exploring the brine microbiota of a traditional Norwegian fermented fish product (Rakfisk) from six different producers during two consecutive seasonal productions. Foods 8: 72. DOI: 10.3390/foods8020072.

Bokulich NA, Subramanian SF, Faith JJ, Gavers D, Knight R, Mills DA, Caporaso JG. 2013. Quality-filtering vastly improves diversity estimates from illumina amplicon sequencing. Nat Methods 10 (1): 57-59.

Caporaso JG, Kuczynski J, Stombaugh J, Bittinger K, Bushman FD, Costello EK, Fierer N, Peña AG, Goodrich JK, Gordon JI, Huttley GA, Kelley ST, Knights D, Koenig JE, Ley RE, Lozupone CA McDonald D, Muegge BD, Pirrung M, Reeder J, Sevinsky JR, Turnbaugh PJ, Walters WA, Widmann J, Yatsunenko T, Zaneveld J, Knight R. 2010. QIIME allows analysis of high-throughput community sequencing data. Nat Methods 7 (5): 335-336.

Castellano P, Ibarreche MP, Massani MB, Fontana C, Vignolo GM. 2017. Review: Strategies for pathogen biocontrol using lactic acid bacteria and their metabolites: a focus on meat ecosystems and industrial environments. Microorganisms 5 : 38. DOI: 10.3390/microorganisms5030038.

Edgar RC, Haas BJ, Clemente JC, Quine C, Knight R. 2011. UCHIME improves sensitivity and speed of chimera detection. Bioinformatics 27 (16): 2194-2200.

Edgar RC. 2013. UPARSE: highly accurate OTU sequences from microbial amplicon reads. Nat Methods 10: 996-998.

Gevers D, Huys G, Swings J. 2001. Applicability of rep-PCR fingerprinting for identification of Lactobacillus species. FEMS Microbiol Lett 205 (1): 31-36.

Gupta S, Ravindra, Maurya PK, Parhi J, Sharma S, Chandravanshi S, Majumdar RK. 2018. Isolation and characterization of predominan bacteria, Staphylococcus piscifermentans associated with traditional fermented fish products of Northeast India. Int J Curr Microbiol App Sci 7 (5): 1758-1771

Hajar S, Hamid THTA. 2013. Isolation of Lactic acid bacteria strains Staphylococcus piscifermentans from Malaysian traditional fermented shrimp cincaluk. Intl Food Res J 20 (1): 125-129.

Lahiri DK, Schnabel B. 1993. DNA isolation by a rapid method from human blood samples: effects of $\mathrm{MgCl}_{2}$, EDTA, storage time, and temperature on DNA yield and quality. Biochem Genet 31 (7-8): 321 328.

Lavefve L, Marasini D, Carbonero F. 2019. Microbial ecology of fermented vegetables and non-alcoholic drinks and current knowledge on their impact on human health. In: Toldra F (eds) Advances in Food and Nutrition Research vol. 87. Academic Press, Oxford, U.K.

Linares DM, Gomez C, Renes E, Fresno JM, Tornadijo ME, Ross RP, Stanton C. 2017. Lactic acid bacteria and bifidobacteria with potential to design natural biofunctional health-promoting dairy foods. Front Microbiol 8: 846. DOI: 10.3389/fmicb.2017.00846.
Magoč T, Salzberg SL. 2011 FLASH: fast length adjustment of short reads to improve genome assemblies. Bioinformatics 27 (21): 2957-2963.

Majumdar RK, Roy D, Bejjanki S, Bhaskar N. 2016. Chemical and microbial properties of shidal, a traditional fermented fish of Northeast India. J Food Sci Technol 53 (1): 401-410.

Manguntungi B, Saputri, DS, Afgani CA, Mustopa AZ, Fatimah, Kusmiran A. 2020. Biodiversity of Enterobacteriaceae on masin (fermented sauce) from Sumbawa, West Nusa Tenggara, Indonesia. Biodiversitas 21: 1001-1006.

Mekadim C, Killer J, Mrázek J, Bunešová V, Pechar R, Hroncová Z, Vlková E. 2018. Evaluation of the $\inf B$ and $r p s B$ gene fragments as genetic markers intended for identification and phylogenetic analysis of particular representatives of the order Lactobacillales. Arch Microbiol 200 (10): 1427-1437.

Mohania D, Nagpal R, Kumar M, Bhardwaj A, Yadav M, Jain S, Marotta F, Singh V, Parkash O, Yadav H. 2008. Molecular approaches for identification and characterization of Lactic acid bacteria. J Dig Dis 9 (4): 190-198.

Mokoena MP, Mutanda T, Olaniran AO. 2016. Perspectives on the probiotic potential of Lactic acid bacteria from African traditional fermented foods and beverages. Food Nutr Res 60: 1. DOI: 10.3402/fnrv60.29630.

Muryany I, Salwany I, Ghazali AR, Hing HL, Fadilah, N. 2017. Identification and characterization of the Lactic acid bacteria isolated from Malaysian fermented fish (Pekasam). Intl Food Res J 24 (2): 868-875.

Nga TT, Tra DX, Ha LT. 2017. Isolation of halophilic lactic bacteria Tetragenococcus Halophilus from Vietnamese fish sauce. Vietnam J Sci Technol 55: 186-194.

Ouobaa LII, Mbozoc ABV, Anyogud A, Obiohaa PI, Sawadogoe HL, Sutherland JP, Jespersenf L, Ghoddusia HB. 2019. Environmental heterogeneity of Staphylococcus species from alkaline fermented foods and associated toxins and antimicrobial resistance genetic elements. Intl J Food Microbiol 311: 108356. DOI: 10.1016/j.ijfoodmicro.2019.108356.

Pessione E, Cirrincione S. 2016. Review: Bioactive molecules released in food by lactic acid bacteria: encrypted peptides and biogenic amines. Front Microbiol 7: 876. DOI: 10.3389/fmicb.2016.00876.

Putra TF, Suprapto H, Tjahjaningsih W, Pramono H. 2018. The antagonistic activity of Lactic acid bacteria isolated from peda, an Indonesian traditional fermented fish. IOP Conf Ser: Earth Environ Sci 137 (2018): 012060. DOI: 10.1088/1755-1315/137/1/012060.

Quast C, Pruesse E, Yilmas P, Gerken J, Schweer T, Yarza P, Peplies J, Glockner FO. 2013. The SILVA ribosomal RNA gene database project: improved data processing and web-based tools. Nucl Acids Res 41: 590-596.

Reuter G. 1985. Elective and selective media for Lactic acid bacteria. Int J Food Microbiol 2: 55-68.

Silva VP, Pareira OG, Leandro ES, Da Silva TC, Ribeiro KG, Mantovani HC, Santos SA. 2016. Effects of Lactic acid bacteria with bacteriocinogenic potential on the fermentation profile and chemical composition of alfalfa silage in tropical conditions. J Dairy Sci 99: 1895-1902.

Speranza B, Racioppo A, Beneduce L, Bevilacqua A, Sinigaglia M, Corbo MR. 2017. Autochthonous Lactic acid bacteria with probiotic aptitudes as starter cultures for fish-based products. Food Microbiol 65: 244-253.

Subagiyo, Margino S, Triyanto, Setyati WA. 2015. Pengaruh pH, suhu dan salinitas terhadap pertumbuhan dan produksi asam organik bakteri asam laktat yang diisolasi dari intestinum udang penaeid. Ilmu Kelautan 20 (4): 187-194. [Indonesian]

Tanasupawat S, Hashimoto Y, Ezaki T, Kozaki M, Komagata K. 1992. Staphylococcus piscifermentans sp. nov., from fermented fish in Thailand. Intl J Syst Bacteriol 42 (4): 577-581.

Woraprayote W, Malila Y, Sorapukdee S, Swetwiwathana A, Benjakul S, Visessanguan W. 2016. Bacteriocins from Lactic acid bacteria and their applications in meat and meat products. Meat Sci 120: 118-132.

Zhang J, Wang X, Huo D, Li W, Hu Q, Xu C, Liu S, Li C. 2016. Metagenomic approach reveals microbial diversity and predictive microbial metabolic pathways in Yucha, a traditional Li fermented food. Sci Rep 6 (1): 1-9. DOI: 10.1038/srep32524.

Zhao CC, Eun JB. 2020. Shotgun metagenomics approach reveals the bacterial community and metabolic pathways in commercial hongeo product, a traditional Korean fermented skate product. Food Res Int 131: 109030.. DOI: 10.1016/j.foodres.2020.109030. 